\title{
EFFECT OF MOSAIC ON THE YIELD OF SUGARCANE VARIETY B. 34-104
}

\section{P. González Rios and J. Adsuar ${ }^{1}$}

\section{INTRODUCTION}

Since the importation into the Island and planting on large scale of mosaic-resistant P.O.J. sugarcane varieties, and the development and production of the Puerto Rico and Mayagüez resistant sugarcane seedlings by the Island and Federal Experiment Stations, respectively, sugarcane mosaic has been practically under control in Puerto Rico. This magnificent accomplishment should not obscure the fact that we are, so to speak, living with the disease, and that the virus is still present in the Island ready to strike with frightful consequences whenever an opportunity is offered in the form of a susceptible variety, no matter how good its other agronomic qualities might be.

The recent introduction of the Barbados seedlings, B. 34-104 and B. 37-161, clearly demonstrates this. Because of their excellent agronomic qualities these two canes, especially B. 34-104, have been increasing in popularity with the growers of the Island. According to reports from Jamaica, B. 34-104 is unaffected by the strain of mosaic found there. Depending on that information our growers have extensively propagated this variety. Preliminary observations, however, indicated that both varieties, especially B. 34-104, were highly susceptible to the sugarcane mosaic virus present in Puerto Rico. But this now generally admitted fact has not yet tempered the enthusiasm of many growers who still claim, not only that B. 34-104 recovers from the mosaic, but that, even when infected, it yields more sugar per acre than many of the standard varieties grown in the Island.

The results obtained with these canes at the Station during the past two years have failed to substantiate these claims. Cane stools of both varieties which were infected in the laboratory and transplanted to the field, were carefully observed for a period of 3 years. No sign of recovery appeared either in the plant cane or in the ratoons of B. 34-104. Variety B. 37-161 showed a high degree of tolerance but did not seem to recover from mosaic.

The purpose of this paper is to present the results obtained from a field trial to determine the effect of cane mosaic on the sugar yield of B. 34-104.

${ }_{1}$ Plant Breeder and Plant Pathologist, respectively, Agricultural Experiment Station, University of Puerto Rico, Río Piedras, P. R. 


\section{MATERIALS AND METHODS}

Shortly after the sugarcane grinding season of 1950 was over an inspection was made of the fields planted to the variety B. 34-104 in the Yabucoa, Humacao, and Caguas districts, with the object of estimating the degree of mosaic infestation to which it was subject in these areas. It was observed that mosaic was spreading here very rapidly, in fact, as fast as new plantings were made with seed obtained from seedbeds with slight to medium infestation. Counts as high as 50 percent were obtained in the Caguas district 4 months after the 1950 spring plantings were made. In Humacao and Yabucoa the same situation was encountered, the percentage of infection observed being still higher in the first and second ratoons. It was the general belief of many farmers in these areas that the mosaic attacking B. 34-104 did not affect the yield of the variety and even that it recovered from the disease. Close observations made by the Plant Breeding and the Plant Pathology Departments indicated that this was not the case, and therefore, it was decided to set up an experiment at the Agricultural Experiment Station in Río Piedras.

The mosaic-infected material for planting the experiment was obtained from the Yabucoa area. The disease-free material was obtained from the Isabela Substation, where B. 34-104 was inspected and found to be free from mosaic. As checks for comparison two highly mosaic-resistant varieties were used: P.O.J. 2878 and P.R. 902.

The site for the experiment was selected on a Vega Baja silty clay soil type. Two plowings and two harrowings were given to the land during the month of May 1950, before planting. The field was furrowed wis a double moldboard plow, making furrows 4 feet apart and to a depth of about 14 inches. Small ditches (sangrias) were opened to insure appropriate drainage and the plots were marked out.

Each plot consisted of four furrows 18 feet long, equivalent to an area of one one-hundred-fiftieth of an acre. A randomized complete block design was used in laying out the experiment. Each treatment was replicated 12 times. Twenty seed-cane cuttings, each with three eyes, were planted in each furrow using a total of 80 seed pieces per plot. Two rows of canes of the variety P.O.J. 2878 were planted around each individual plot to serve as a buffer and to protect against secondary infection from the mosaicinfected plots of B. 34-104.

The plots were planted on June 26, 1950. A 14-4-10 fertilizer was used in a single application 1 month after planting, at the rate of 1,000 pounds per acre. Three weedings were made during the early growing season and the plots were harvested on June 6, 1951, when the crop was $111 / 2$ months old.

The experiment was carried on for another year in order to observe the 


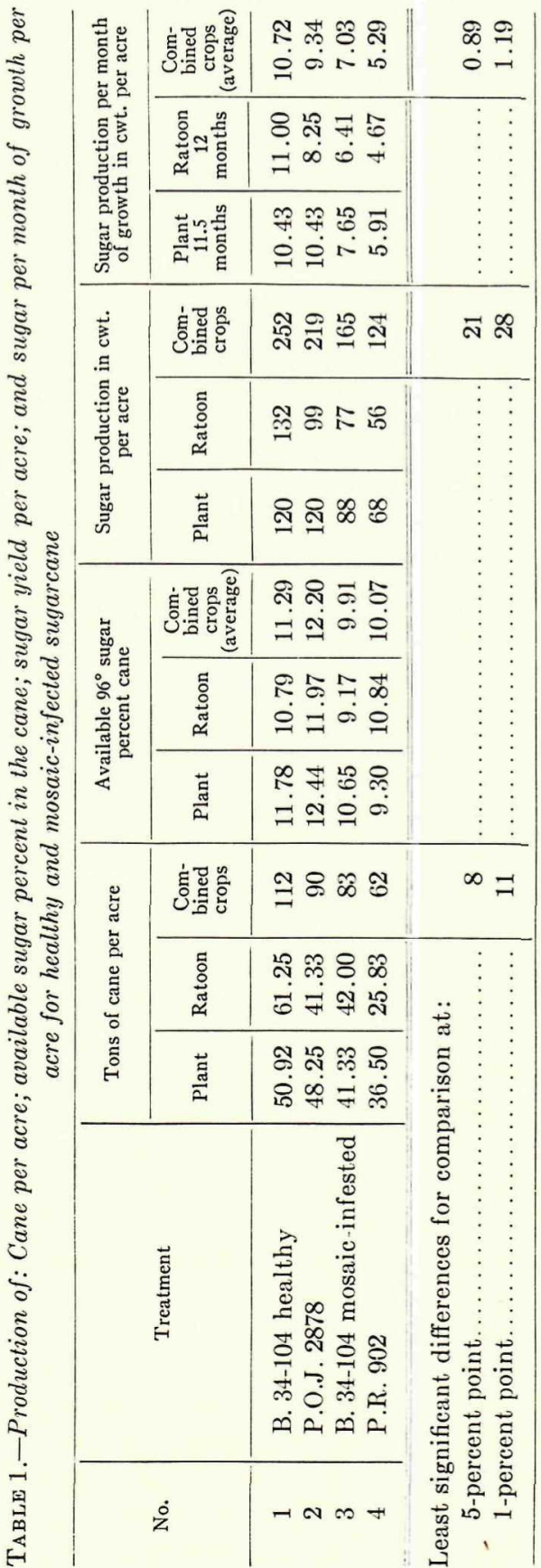


effect of mosaic on the ratoon crop. The trash was aligned in alternate rows and cultivation practiced in the clean banks. Some replanting had to be done on the diseased plots of B. 34-104, while very little was required by either healthy or check plots. A single application of fertilizer was made to the ratoon crop at a rate of 800 pounds per acre of sulfate of ammonia. Two weedings were necessary to keep the cane clean of weeds. The plots were harvested for the second time on June 2, 1952, when the ratoon crop was 12 months old.

Periodical counts were made on the healthy plots for diseased stools caused by secondary infections both on the plant cane during the first year and the ratoon cane during the second year.

In each harvesting the plots were cut and the cane was weighed right in the field by using a portable weighing outfit. Ten cane stalks cut at full length were selected at random from each plot weighed, ground in a Squier hydraulic mill, and the extracted juice weighed and analyzed to determine the available sugar content.

\section{EXPERIMENTAL DATA}

Quantitative data on the effect of sugarcane mosaic on the production of cane stalks and yield of sugar are given in table 1 . The production of cane is given in tons of 2,000 pounds per acre. The yield is given in hundredweights of sugar of $96^{\circ}$ polarization and the available sugar in the cane as available $96^{\circ}$ sugar percent cane.

\section{DISCUSSION}

The mosaic-infected plots of B. 34-104 remained 100-percent infected throughout the 2-year duration of the experiment. Not a single case of recovery was noticed in any of the diseased plots. During the first year only one stool was observed with mosaic in the healthy plots. Stool-counting inspections were performed every month up to the tenth month of growth when the cane stalks were too entangled to permit entering the plots.

The statistical analysis of the results shows that the cane yield of the healthy B. 34-104 was 29-percent superior to that of B. 34-104 with mosaic in the plant-cane crop, and 32-percent higher in the ratoon crop. The average available sugar content of the cane in the healthy B. 34-104 was 11.29 percent against 9.91 percent for the diseased cane, or a deficiency of 12.23 for the latter in the total sugar content (table 1).

The production of sugar $96^{\circ}$ polarization by the healthy B. 34-104 when harvested as plant cane during the first year was 26.7 percent higher than the production by the diseased cane, and 41.7 percent higher when cut as a ratoon crop during the second year. These same percentages were obtained in calculating the per month production of sugar per acre for the healthy and the infected cane (table 1). It has been clearly demonstrated 
that there is a great reduction in the sugar content of the diseased plants in the ratoon stage as compared with the plant crop. It was also shown that the difference in sugar content percent cane between the healthy and diseased canes was only 3 percent, while the difference in sugar production in hundredweights per acre was 15 percent, or five times as much.

If the variety B. 34-104 could be maintained free of mosaic it would produce a little more total sugar per acre than P.O.J. 2878 in the Río Piedras area, but with a greater tonnage to be cut and hauled and, in the long run, it would prove to be less profitable than P.O.J. 2878.

Variety P.R. 902 proved unadapted to Río Piedras conditions. This checks with the results of previous variety trials.

\section{SUMMARY}

Many farmers in Puerto Rico believe that the sugarcane variety B. 34104, although susceptible to mosaic, can produce more sugar than the current known commercial varieties, and that this variety recovers from the disease. Preliminary investigations by technical staff members of the Agricultural Experiment Station did not confirm this. A controlled experiment was carried out and the following conclusions were drawn:

1. Once the canes of variety B. 34-104 are infected with the common sugarcane mosaic prevailing in the Island they do not recover from the disease, and infected seed produces diseased plants.

2. There was a reduction of 29 percent in tonnage production in the plant cane crop and of 32 percent in the first ratoon crop attributable to the disease.

3. There was a difference of 26.7 percent in the production of $96^{\circ}$ sugar per acre in the plant cane crop and of 41.7 percent in the first ratoon crop between the healthy and infected canes.

4. If B. 34-104 could be maintained free from mosaic it would produce about the same quantity of sugar as P.O.J. 2878, but a greater tonnage would have to be handled and processed, and profits would be lower.

\section{RESUMEN}

Los agricultores de caña en Puerto Rico han estado creyendo que la variedad B. 34-104, a pesar de ser susceptible al mosaico, puede producir mayor cantidad de azúcar que cualquiera de las variedades comerciales corrientes cultivadas en la Isla y que también hasta puede sanar de la enfermedad. En investigaciones preliminares llevadas a cabo por miembros del personal técnico de la Estación Experimental se observó que esta creencia no está justificada. Al efecto, se llevó a cabo un experimento controlado, del cual se derivaron las conclusiones siguientes:

1. Una vez que las cañas de la variedad B. 34-104 adquieren la infección 
con el mosaico común prevaleciente en la Isla no vuelven a recobrar de la enfermedad; además, cañas enfermas usadas como semilla producen plantas enfermas.

2. Se obtuvieron diferencias en tonelaje de 29 porciento en plantilla y de 32 porciento en retoño entre la variedad sana y la enferma.

3. Las reducciones obtenidas en la producción de azúcar por cuerda debidas a la enfermedad fueron de 26.7 porciento en la plantilla y de 41.7 en el retoño.

4. La variedad B. 34-104 mantenida libre de mosaico produce tanta azúcar como la variedad P.O.J.-2878, pero produce un mayor tonelaje. 